\title{
DID PAUL CAUSE AN INTERPOLATION IN THE SECOND CODE? A glance into the kitchen of Justinian's codification project
}

We know of Justinian that he ordered the committees who drew up the various law codes to change the texts if necessary. These so-called interpolations have been, and still are hotly debated, because no one knows the exact amount of changes carried through. Nowadays scholars tend to think there were a lot less changes made, contrary to what their twentiethcentury predecessors thought. Whereas these predecessors very often based their suspicions of interpolations on purely linguistic grounds, nowadays we tend to require some kind of external evidence as basis for a suspicion of interpolation. ${ }^{1}$

What is interesting about all this is, to my mind, not the bare question whether texts have been altered, but how the committees went about this business. Would it not be nice to have a glimpse through the kitchen window, a look into the boiler-room of Justinian's codification project? Is this still possible after all this time? Perhaps not. But would it not be lovely to have a little peek around the corner? I will try to take you on a little trip in an attempt to have this furtive glance. No doubt I will fail in offering you this miniature picture of legislative activity. But it will perhaps be worth the effort. Our road will lead us to a couple of Basilica scholia on changes in the law of dowry.

The Basilica scholia offer one of the most explicit references to an interpolation in Justinian's codes. What is special about this particular reference is that is contemporaneous with the codification project. The reference occurs in the old sixth-century scholia on the Basilica. The reference reads as follows:

1 J.H.A. Lokin, 'The End of an Epoch. Epilegomena to a Century of Interpolation Criticism', in R. Feenstra / A.S. Hartkamp / J.E. Spruit / P.J. Sijpesteijn / L.C. Winkel (eds.), Collatio iuris romani. Études dédiées à Hans Ankum à l'occasion de son $65^{e}$ anniversaire, Tome I, (Studia Amstelodamensia ad epigraphicam, ius antiquum et papyrologicam pertinentia, Vol. XXXV, A), Amsterdam 1995, pp. 261-273 (repr. in: J.H.A. Lokin, Analecta Groningana ad ius graeco-romanum pertinentia, (ed. Th.E. van Bochove), Groningen 2010, pp. 17-30. 
BS 2135/1-2 (sch. F 2 ad B. $29,5,37=$ C. $5,14,7$ )

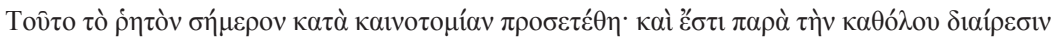

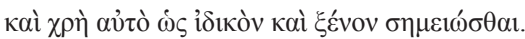

'This part of the Latin text has now been added in accordance with a change in the law; and it is against the general determination and needs to be noted as special and new'.

First, let us look at the Basilica and their scholia, to explain their significance in order to find out what went on in Justinian's boiler-room. ${ }^{2}$ The Basilica are in essence a collection of Greek versions of Justinian's law codes. The term means 'Imperial', and is an abbreviation of the phrase $\tau \grave{\alpha} \beta \alpha \sigma i \lambda \iota \kappa \grave{\alpha}$ vó $\mu \mu \alpha \alpha$, the imperial laws. This collection was completed during the reign of the emperor Leo VI, also known as Leo the Wise, who ruled from the year $886 \mathrm{AD}$ until the year $912 \mathrm{AD}$. So there is nothing contemporaneous with the Justinianic age in the making of this collection. The texts used, however, were sixth-century versions. The text of the Basilica consisted of 60 books. These books were subdivided into titles. Ideally, every title contained Greek versions of provisions from the Digest, the Code and the Novels, all pertaining to the same subject matter. A little later, during the tenth century, the so-called old scholia were added to the Basilica text. These scholia presented more Greek versions of the same texts. The reason why more versions of the same texts were added is that the original Latin texts of Justinian's codes were still the texts in force, which had to be applied. Comparison of more versions could lead to a better understanding of the law to be applied. Especially where, as in the case of the Digest, the version used in the text of the Basilica was a summary version. ${ }^{3}$ There are also so-called new scholia to the Basilica. These new scholia were written and added to the Basilica text throughout the eleventh century, and later. They are of much later date than Justinian's own age. So if we are in search of material from the scholia contemporaneous with Justinian, we first have to locate the old scholia. Then we have to try and find out which author wrote the scholion. That is because not all sixth-century material stems from the days of Justinian's codifying

2 See for the following e.g. N. van der Wal / J.H.A. Lokin, Historiae iuris graeco-romani delineatio. Les sources du droit byzantin de 300 à 1453, Groningen 1985, pp. 81ff., 90ff., 99ff. Cf. also Th.E. van Bochove, Basilica Online Bibliography (https://referenceworks.brillonline.com/browse/basilica-online, Tab Bibliography), Nos. 107-112 (general), 158-162 (Basilica text), and 242-246 (Basilica scholia).

3 Cf. for a second reason for the addition of the old scholia to the Basilica in the tenth century, i.e. the phenomenon of 'Byzantine Encyclopaedism', or rather the 'cultura della $\sigma 0 \lambda \lambda \sigma \gamma \eta$ ', or 'culture du recueil' during the reign of emperor Constantine VII Porphyrogennetos, Th.E. van Bochove, 'Tenth Century Constantinople: Centre of Legal Learning? Second thoughts concerning the addition of the older scholia to the Basilica text', FM XII (2014), pp. 69-96, esp. p. 79ff. 
project. Some of it is from a little later date. So, after isolating texts stemming from authors writing in the days of Justinian and his law codes, we have sources at hand, which may provide a clue to the way in which this project was carried out. ${ }^{4}$

Now let us return to the scholion we just read, about the change in the law of dowry. It is probably Thalelaeus who is telling us about this interpolation. Thalelaeus was an antecessor (professor of law) in the days of Justinian of whom we have testimony regarding his lectures on the Code of Justinian, found in the text and scholia on the Basilica. ${ }^{5}$ The text he is commenting upon here is taken from Justinian's Code. That this scholion is taken from a sixth-century commentator is proved by the use of the word $\rho \eta \tau$ òv, which in this case refers to the Latin text of the Code itself. ${ }^{6}$ That it is Thalelaeus who is the author of the scholion follows, amongst other things, from a comparison with similar utterances ascribed to him and collected by Dieter Simon.

The text of the Code commented upon is C. 5,14,7:

Idem AA (Imperatores Diocletianus et Maximianus) et CC. Phileto. Pater, pro filia dotem datam genero ea prius in matrimonio defuncta nepotibus pactus restitui, licet his actionem quaerere non potuit, tamen utilis eis ex aequitate accommodabitur actio. D. XIIII K. Ian. Nicomediae CC. conss. $<$ A. 294>

'The same Augusti (Diocletian and Maximian) and Caesars to Philetus. A father gave a dowry to his son-in-law on behalf of his daughter and made an agreement that, if the marriage were ended by her death, the dowry would be given back to his grandchildren. Although he could not acquire a right of action for them, an analogous action will nevertheless be framed for

4 Cf. about the way to distinguish old from new scholia in general Van Bochove, Basilica Online Bibliography (supra n. 2), Nos. 10-16, and 247-251.

5 Cf. e.g. Van der Wal / Lokin, Delineatio (supra n. 2), p. 42f. See especially S. Sciortino, 'Conjectures regarding Thalelaios' commentary on the Novus Codex', SG IX (2014), pp. 157-185. Cf. also Van Bochove, Basilica Online Bibliography (supra n. 2), Nos. 471-487.

$6 \quad$ Cf. H.J. Scheltema, L'enseignement de droit des antécesseurs, (Byzantina neerlandica. Series B: Studia, I), Leiden 1970, pp. 10, 14, 32ff. (repr. in H.J. Scheltema, Opera minora ad iuris historiam pertinentia, (collegerunt N. van der Wal, J.H.A. Lokin, B.H. Stolte, Roos Meijering), Groningen 2004, pp. 58-110 (66, 69, 81ff.)).

7 D. Simon, 'Aus dem Kodexunterricht des Thalelaios'. A: Methode, SZ 86 (1969), pp. 334-383; B: Die Heroen, SZ 87 (1970), pp. 315-394; C: Interpolationsberichte, RIDA, $3^{\mathrm{e}}$ série, 16 (1969), pp. 283-308; D: Divergenzen zwischen Thalelaioskommentar und Codexüberlieferung', RIDA, $3^{\mathrm{e}}$ série, 17 (1970), pp. 273-311. 


\section{BRANDSMA}

them from reasons of equity (aequitas). Given December 19, at Nicomedia, in the consulship of the Caesars' (294). ${ }^{8}$

The father of a bride gave his son-in-law a dowry. In doing so he agreed with his son in law that if his daughter should die first during the marriage, the dowry should be given to his grandchildren, the sons born from the marriage. The question the emperors had to answer was whether the sons could sue their father on the basis of this agreement. The answer was that the grandfather could not grant his grandchildren a right of action in this way. They were, however, given an actio utilis by reason of equity.

The part of the text Thalelaeus is referring to is the final sentence of the constitution giving the actio utilis to the grandchildren. This part is remarkable, because the grandfather who gave his daughter a dowry and stipulated it should be returned to his grandchildren should the daughter die during marriage, could not provide them with a right of action, as the ban on stipulations on behalf of third parties prevented this generally speaking. ${ }^{9}$ This will be the general provision Thalelaeus is referring to in the scholion, by means of the

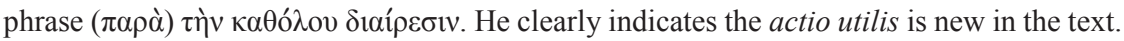
It is there now, бๆ $\mu \varepsilon \rho o v$. That means it was not there when Diocletian and Maximian issued their constitution. It was added, $\pi \rho 0 \sigma \varepsilon \tau \varepsilon \dot{\theta} \eta$. Moreover, the addition was made because of a

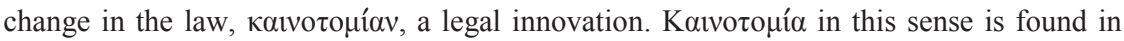
several other Basilica scholia as well. ${ }^{10}$ Simon concluded he could not make out whether this interpolation occurred only in the second Code, as most other changes he discussed, or that it was already made in the first Code. ${ }^{11}$

8 Transl. T.A.J. McGinn, in B.W. Frier (ed.), The Codex of Justinian. A New Annotated Translation, with Parallel Latin and Greek Text. Based on a Translation by Justice Fred H. Blume, Cambridge 2016, (3 vols.), Vol. II, p. 1203.

9 Cf. e.g. G. Wesenberg, Verträge zugunsten Dritter. Rechtsgeschichtliches und Rechtsvergleichendes, (Forschungen zum römischen Recht, I. Band, 2. Abhandlung), Weimar 1949, pp. 48ff.; see also, more recently, Th. Finkenauer, Vererblichkeit und Drittwirkungen der Stipulation im klassischen römischen Recht, (Tübinger Rechtswissenschaftliche Abhandlungen, 108), Tübingen 2010, pp. 15ff. (esp. n. 15), who, however, speaks of 'gewichtige Ausnahmen die Juristen in der Spätklassik von diesem Grundsatz machen'; J.D. Harke, Actio utilis. Anspruchsanalogie im römischen Recht, (Schriften zur Rechtsgeschichte, Band 175), Berlin 2016, pp. $291 \mathrm{ff}$.

10 Cf. BS 433/10 (sch. Ca 1 ad B. 11,2,60=C. 2,4,43; Theodorus); BS 1265/5 (sch. Pa 2 ad B. 21,1,43= C. 4,20,19; Theodorus); BS 2010/11 (sch. F, Pa 2 ad B. 29,1,24 = D. 23,3,28; Enantiophanes); BS 2297/32, 2298/34 and 2299/29 (sch. Pb 1 ad B. 39,1,6 = D. 5,2,6; Stephanus); BS 2341/4 and 5 (sch. $\mathrm{Pb} 3$ ad B. 39,1,52=C. 3,28,27; Thalelaeus); BS 2469/12 (sch. Pb 4 ad B. 41,4,5= C. 3,29,5; Thalelaeus); BS 2491/27 (sch. Pb 1 ad B. 41,7,36 (35)=C. 6,20,20; Theodorus); BS 2496/21 (sch. Pb 3 ad B. $42,1,3=$ D. 5,3,3; Stephanus).

11 Cf. Simon, 'Kodexunterricht des Thalelaios. C: Interpolationsberichte' (supra n. 7), p. 302f. 


\section{DID PAUL CAUSE AN INTERPOLATION IN THE SECOND CODE?}

Therefore, what we have here is a clear indication of a legal innovation, which led to an interpolation. That was already noticed long ago. ${ }^{12}$ The question is, however, whether this innovation was made solely by this interpolation, or whether this interpolation was a result of something else. Before I embark upon an attempt to answer this question, I want to take you to a related case, to be found in the Digest:

\section{D. $24,3,45$}

Paulus libro sexto quaestionum. Gaius Seius avus maternus Seiae nepti, quae erat in patris potestate, certam pecuniae quantitatem dotis nomine Lucio Titio marito dedit et instrumento dotali huiusmodi pactum et stipulationem complexus est: "Si inter Lucium Titium maritum et Seiam divortium sine culpa mulieris factum esset, dos omnis Seiae uxori vel Gaio Seio avo materno redderetur restituereturque". Quaero, cum Seius avus maternus statim vita defunctus sit et Seia postea sine culpa sua divorterit vivo patre suo, in cuius potestate est, an et cui actio ex hoc pacto et stipulatione competat et utrum heredi avi materni ex stipulatu an nepti. Respondi in persona quidem neptis videri inutiliter stipulationem esse conceptam, quoniam avus maternus ei stipulatus proponitur: quod cum ita est, heredi stipulatoris, quandoque divorterit mulier, actio competere videtur. Sed dicendum est Seiae posse dotem solvi (quamvis actio ei directo non competat), ac si sibi aut illi dari avus stipulatus esset. Sed permittendum est nepti ex hac avita conventione, ne commodo dotis defrudetur, utilem actionem: favore enim nuptiarum et maxime propter affectionem personarum ad hoc decurrendum est.

'Paul, Questions, Book VI. Gaius Seius, the maternal grandfather of Seia, who was under paternal control, gave a certain sum of money by way of dowry to Lucius Titius, her husband, and inserted in the dotal instrument the following agreement and stipulation: "If a divorce should take place between Lucius Titius, the husband, and Seia, without her fault, all the dowry shall be returned to Seia, his wife, or to Gaius Seius, her maternal grandfather". I ask, if Seius, the maternal grandfather, should die immediately after making this agreement, and Seia should subsequently, without being to blame, be divorced during the lifetime of her father, under whose control she was, in favour of whom an action would lie under the agreement and the stipulation, of the heir of the maternal grandfather, or of his granddaughter. I answered that the stipulation would seem to be void, as far as the granddaughter personally was concerned, as the maternal grandfather made the stipulation in her favour; for, since this

12 For instance, Antoine Favre wrote about it; cf. his Conjecturarum iuris civilis libri viginti, Lyon 1581 ff. (ed. 1661), lib. XIX, c. 19, No 9 ff., esp. 13 and 15. 
is true, a right of action would be held to lie in favour of the heir of the stipulator, whenever the woman was divorced. It must be said, however, that the dowry can be paid to Seia, even though no action will lie directly in her favour; just as if her grandfather had stipulated that it should be given to him, or to someone else. ${ }^{13}$ The granddaughter ought, however, on account of the agreement of her grandfather, to be permitted to bring an actio utilis to prevent her from being defrauded of the benefit of the dowry; recourse to this should be had because of the favour conceded to marriage, and especially on account of the affection existing between the parties'. ${ }^{14}$

This is a very long and somewhat complicated text. The case is not quite the same as the one from the Code. Here it is not the father, but the grandfather, Gaius Seius, who provides the husband of his granddaughter, called Seia, with a sum of money as a dowry. ${ }^{15}$ The grandfather is the father of Seia's mother. This explains why she is not under his control, but under the control of her father. Watson's translation reads 'a granddaughter in his [i.e. the grandfather's] power', but I think that is mistaken, and so do the German and the Dutch translations. ${ }^{16}$ The husband is called Lucius Titius, in the fragment at least, if not in real life. A dotal instrument is drawn up in which the return of the dowry is agreed and stipulated in case of divorce without fault on the part of Seia. The dowry should then be handed over to Seia or handed back to Gaius Seius, the grandfather. The grandfather dies and Seia is divorced without her fault. The question Paul asked himself was who then would have the right of action. Would that be the heir of the grandfather, whoever that may be, or would it be Seia? Paul answers in a very extensive way. He explains there is no direct action on behalf of Seia. The grandfather could not stipulate on behalf of his granddaughter. ${ }^{17} \mathrm{He}$ then explains the dowry could have been paid validly to Seia, just as if the grandfather had stipulated the sum to be paid to himself or someone else. He must have thought here of the

13 Cf. D. $46,3,10$ and D. 46,3,12,3.

14 Translation based on S.P. Scott, The Civil law, Including The Twelve Tables, The Institutes of Gaius, The Rules of Ulpian, The Opinions of Paulus, The Enactments of Justinian, and The Constitutions of Leo: Translated from the original Latin, Cincinnati 1932, vol. 6, p. 19f., with slight alterations. See for the reason why I preferred this translation to Watson's in this instance below in the text near footnote 16 .

15 The names suggest it is a textbook case.

16 The Digest of Justinian. English translation edited by A. Watson, Philadelphia 1985, vol. 2, p. 726a; O. Behrends, R. Knütel et alii (Hrsg.), Corpus Iuris Civilis. Text und Übersetzung, IV: Digesten 2127, Heidelberg 2005, p. 296 ('die in der Hausgewalt ihres Vaters stand'); J.E. Spruit et alii (red.), Corpus Iuris Civilis. Tekst en Vertaling, III: Digesten 11-24, Zutphen/'s-Gravenhage 1996, p. 913 ('die onder het gezag van haar vader stond').

17 If she had been under his control, there would be no problem. This is what the Watson-translation appears to overlook. 
case of an solutionis causa adiectus. ${ }^{18}$ Such a person to whom a debt due to another could be paid was not a creditor himself, but payment to the adiectus freed the debtor from his obligation. The adiectus was entitled to receive payment, not to exact it. Then all of a sudden Paul suggests the granddaughter should be given an actio utilis. He goes on to explain this. The granddaughter should be prevented from being defrauded of the benefit of her dowry. She should not be the victim of the legally clumsy way in which the grandfather went about his business, we could perhaps read Paul to mean. The favour to the marriage and the affection of the parties, meaning the grandfather and his granddaughter, should be counted as arguments to follow this course.

Of course, the rather sudden change of direction in the answer Paul gives has been taken to indicate the granting of the actio utilis here to be interpolated. ${ }^{19}$ Other voices say the extensive answer rather points in the direction of an authentic reply given by Paul to the question he asked himself. ${ }^{20}$ Be that as it may, I want to point out another possibility, an intriguing one, I might add.

I want to confront you with a remarkable utterance by Dorotheus, who translated this Digest text. Dorotheus, too, was a law professor from the days of Justinian. In fact, he was not only a law professor - in Beirut that is - but also a member of the committees that drew up the Digest, the Institutes and the Second Code. If there was anyone who knew about the business of making Justinian's law codes, apart from Tribonian and - perhaps - Justinian himself, it was Dorotheus. After being a codificator for a couple of years, he went back to his law school in Beirut and started translating the Digest. He translated not just the books of the Digest dealt with by the law professors in accordance with Justinian's new curriculum, but the entire Digest. ${ }^{21}$ His translation must have had a wider aim than just providing students with the Greek of texts they needed to know. So he does not digress like other law professors, but merely translated. But as translating is also interpreting, he is not able to shy

18 Cf. e,g. Chr. Schnabel, Der solutionis causa adiectus im römischen Recht, (Münchener Beiträge zur Papyrusforschung und antiken Rechtsgeschichte, Heft 110), München 2015.

19 See Harke, Actio utilis (supra n. 9), esp. p. 293. See also Wesenberg, Verträge zugunsten Dritter (supra n. 9); R. Sotty, Recherche sur les utiles actiones. La notion d'action utile en droit romain classique, Grenoble 1977, pp. 425ff., and e.g. J. Schmidt-Ott, Pauli Quaestiones. Eigenart und Textgeschichte einer spätklassischen Juristenschrift, (Freiburger Rechtsgeschichtliche Abhandlungen. N. F., 18), Berlin 1993, pp. 182ff., with references. On the other hand, Finkenauer, Vererblichkeit und Drittwirkungen (supra n. 9), p. 16, n. 15, states in general: 'Die geäußerten Verdächtigungen haben alle zur Voraussetzung, daß die römischen Juristen sich an ihre Rechtsregel alteri stipulari nemo potest sklavisch gehalten hätten; genau dies ist aber sehr unwahrscheinlich'. With regard to C. 5,14,7, however, it should be stressed the interpolation is proven by Thalelaeus' remark.

20 Cf. J.F. Stagl, Favor dotis. Die Privilegierung der Mitgift im System des römischen Rechts, (Forschungen zum Römischen Recht, Abhandlung 53), Wien 2009, pp. 146ff., esp. $151 \mathrm{ff}$.

21 Cf. Van Bochove, Basilica Online Bibliography (supra n. 2), Nos. 324-333. 
away from inserting some clarifications or additions now and again, be it they are small in number and not very extensive in scope..$^{22}$

The rendering of the actio utilis in the last part of the above fragment has been under suspicion of being an interpolation since at least the days of Antoine Favre, Faber, who wrote his works around about 1600 . The discussion was mainly about the content of the fragment, which seemed to be in contradiction with the general provision mentioned above and therefore could not stem from Paul.

The traditional line of thought is: the Byzantines made a mess of it. But the so-called Byzantines were no fools. They knew their Homer and they knew their Paul. ${ }^{23}$ So why would they have made a fine text of Paul into an unappealing one? Would not the text of Paul without the granting of the actio utilis be a kind of superfluous statement of already known and long established principles? Hardly worth mentioning? Would he not have been stating the obvious? I believe in the authenticity of Paul's text. The constitution, on the other hand, hardly deserves the praise of a reasoned decision: it is a text smacking of mechanical changes.

As I already said above, a more solid foundation for a suspected interpolation is what tends to be required nowadays: some clue to be found elsewhere in Justinian's codification that leads us to suspect an interpolation. I believe a clue to the contrary can be found thanks to Dorotheus' translation. At the end of his translation of this Digest fragment, he adds something remarkable. Let us take a look, once again, at the last sentence of the Digest fragment. It reads: favore enim nuptiarum et maxime propter affectionem personarum ad hoc decurrendum est, recourse to this should be had because of the favour conceded to marriage, and especially because of the affection existing between the parties. Ad hoc will

22 Cf. on Dorotheus, F. Brandsma, Dorotheus and his Digest translation, Groningen 1996. See also Van Bochove, Basilica Online Bibliography (supra n. 2), Nos. 426-433.

23 Cf. e.g. H.L.W. Nelson, Überlieferung, Aufbau und Stil von Gai Institutiones, (Studia Gaiana. Vol. VI), Leiden 1981, pp. 206 ff., on the stylistic improvements upon Gaius' Institutes made by the lawyers working on Justinian's Institutes: 'Sie haben sich grössere Mühe gegeben, ein grammatisch einwandfreies Latein zu schreiben als Gaius selbst dies getan hatte.' (p. 210); 'Der justinianische sprachliche Ausdruck ist vielerorts "klassischer" als der gajanische.' (p. 211); 'Die Sprache der justinianischen Rechtslehrer weist mit der von Gaius, Paulus und Ulpian und anderen klassischen Autoren eine verblüffende Ähnlichkeit auf und es ist den kaiserlichen Redaktoren gelungen, in sprachlicher und stilistischer Hinsicht ein Intervall von mehr als drei Jahrhunderten zu überspringen.' (p. 211). The same goes for the stylistic improvements in Digest fragments taken from Gaius: 'Das günstige Urteil, das wir inbetreff der Institutionen aussprechen konnten, trifft auch zu auf die Digesten.' (p. 259); 'Das Latein der justinianischen Gaiusfragmente hat des öfteren ein "klassischeres" Gepräge als das des gajanischen Originals.' (p. 260); 'Die von Interpolationenforschern vertretene These, dass die justinianischen Digestenfragmente durch häufige Spätlatinismen, ja sogar "Byzantinismen" verunstaltet seien, muss denn auch, da sie im Widerspruch mit den Tatsachen stehen, zurückgewiesen werden.' (p. 260). These claims are based on scant evidence given by Nelson. 
refer here to the device, the mechanism, if you will, of giving an actio utilis. Now what does Dorotheus make of this? He wrote:

BS 1927/26 (sch. F, Pa 1 ad B. $28,8,43$ = D. 24,3,45)

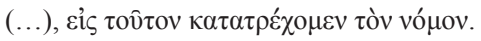

'(...), to this law we have recourse'.

The question, of course, is: what law does he mean? Now once again I would like to stress Dorotheus was a member of both the committee that drew up the Digest, and the committee responsible for the second Code. When changes were made in the texts of both codes by these committees, he is the one who should know. When he is talking here about a law that made this change possible, he could have been referring to some constitution. He does not

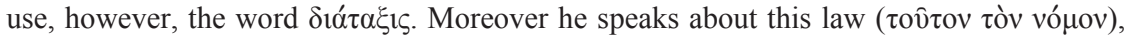
the most obvious meaning of which would be the Digest fragment itself. ${ }^{24}$

One should also be aware of a subtle change that had taken place once the text written by Paul had been adopted into the Digest. First, it is no longer an opinion by Paul, but it now is part of a constitution by Justinian, for which the word lex is in place. Second, the granting of an actio utilis is no longer an independent remedy, to be granted whenever a lawyer finds reason to do so. The only source of law after Justinian's Digest is the imperial legislation, the leges, so it could well be a Justinianic law professor and a co-codificator at that, who tried to subtly bring this change to mind by replacing the talk of a remedy by a reference to 'this law'.

Now, I wonder whether Dorotheus would not have referred to the constitution, if that had been the ultimate source of the actio utilis in this case. Could it perhaps be the other way around? Is it possible the change in C. $5,14,7$ was caused by D. $24,3,45$ ? We would then have to surmise Paul's text to be genuine and the constitution of Diocletian and Maximian to have been in contradiction with it. The original constitution might then have been in the first Code in its original form, denying an action. While working on the Digest Paul's solution was found and preferred above the one given by Diocletian and Maximian.

24 Cf. on the use of $\delta$ เó $\tau \alpha \xi ı$ for constitution H.J. Scheltema, 'Subseciva. III. Die Verweisungen bei den frühbyzantinischen Rechtsgelehrten', TRG 30 (1962), pp. 355-357 (= Scheltema, Opera minora (supra n. 6), pp. 116-118). See also Van Bochove, Basilica Online Bibliography (supra n. 2), Nos. 10-16. 
Simon, in discussing Thalelaeus' remark, said he could in this instance, unlike in other ones, not make out whether the change Thalelaeus discussed was made in the second Code. ${ }^{25}$ If my reasoning is correct, we could now put this case in file with the other cases of changes made in the second Code. ${ }^{26}$ An additional argument could be drawn from the use of the word $\sigma \eta \dot{\mu} \mu \rho \rho v$, to-day, in BS 2135/1, which seems to point to the most recent point in time the change could have been made. Of course, other reasons can be found why C. 5,14,7 was interpolated and not D. 24,3,45. The two instances of an actio utilis given could be quite unrelated. At least the Byzantines of Justinian's day saw the relation between the two texts, witness an interlinear scholion of sixth-century origin:

BS $1928 / 9$ (sch. F, Pa $6 \S$ ad B. $28,8,43=$ D. $24,3,45$ )

'Avó $\gamma v \omega \theta \imath \beta \iota . \varepsilon^{\prime}$ '

'Read book five of the Code, title fourteen, constitution seven'.

This is one of the interlinear scholia, which sometimes occur in the manuscripts of the Basilica. They are written between the lines of the main text of the Basilica. Their age depends upon the way they are phrased. The date of the present scholion is indicated by the use of the word $\delta 1 \alpha$ á $\alpha \xi 1 \zeta$ and the reference to the Code. New scholia, scholia written after the Basilica were compiled, refer to the Basilica themselves and not to the original Justinianic codes.$^{27}$ The above scholion must therefore be an old scholion from Justinian's day. So at least according to the lawyers of the Justinianic age there was some connection between these two texts, the Digest text on the one hand and the constitution from the Code of 529 on the other hand. I suggest this connection is as follows. The constitution as found in the first Code was still the original one. It denied the right of action to the grandchildren. Then, while work on the Digest progressed the solution Paul gave was found. ${ }^{28}$ It appealed to the drafters and they decided, or better still, had Justinian decide, to change the text of

25 Cf. Simon, 'Kodexunterricht des Thalelaios. C: Interpolationsberichte' (supra n. 7), p. $302 f$.

26 See on these changes in general e.g. S. Corcoran, 'Justinian and His Two Codes: Revisiting P. Oxy. 1814', JJP XXXVIII (2008), pp. 73-111, esp. p. 81 ff. about the arguments taken from the works of the sixthcentury antecessores. Cf. on the Code in general S. Corcoran, 'The Codex of Justinian: The Life of a Text through 1,500 Years', in Frier, The Codex of Justinian, Vol. I (supra n. 8), pp. xcvii-clxiv, and the 'Bibliography', pp. clxv-clxxxi.

27 See again Van Bochove, Basilica Online Bibliography (supra n. 2), Nos. 10-16.

28 Cf. for the work on the Digest e.g. T. Honoré, Justinian's Digest. Character and Compilation, Oxford 2010 . 
the constitution in the second Code of 534. The actio utilis was granted to the grandchildren and equity was given as an explanation in a somewhat perfunctory way. Dorotheus knew about the change to come, perhaps even suggested it. He stressed the actio utilis was given by the Digest fragment, the lex, taken from Paul's books of Questions. Dorotheus, too, was a member of the committee that drew up the second Code. To be more precise: he was the only law professor of that committee and together with Tribonian one of the steady forces behind the codification activities of Justinian. Remember he had also been a member of the committee that drew up the Institutes. Thalelaeus was a colleague of Dorotheus from the Beirut law-school who started teaching the Code and writing his commentary upon the Code, while Dorotheus wrote his translation of the Digest.

The above case may well have been one of the instances, which all together gave the committee the idea to start work on a revised edition of the Code.

Therefore, I take it the Digest text here led to the interpolation in the second Code. In this particular case it concerned an interpolation intended to return the law to the more

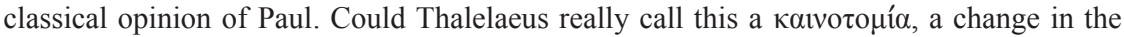
law? Yes, I think he could. If the actio utilis did not occur in the first Code, but was adopted into the Digest by incorporating Paul's opinion, then that opinion amounted to a change in the law, because Paul's opinion only became law in a technical sense at the moment the Digest was promulgated in December 533. That is also, why Dorotheus can qualify Paul's

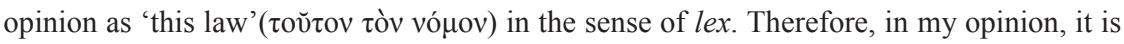
not a change of the classical law, but a return to it.

That leaves unanswered the question whether it is plausible Diocletian and Maximian could have given their rescript in contradiction of a respected lawyer's opinion. Of course it is. They must have known his opinion. And his opinion, no doubt, was one of many. But it was their duty and they had authority to settle the matter. That could explain why what looks like a simple enough question was even a matter for the emperors to decide in a rescript. Perhaps they also concluded their case was quite a different one from the one Paul dealt with. The former is about grandchildren and the latter about a granddaughter. Only the daughter has a special claim to a dowry, of course. In the end, the choice could have gone the other way when the Digest and the first Code were confronted. 
